\title{
Management of Phytophthora capsici Infection in Black Pepper (Piper nigrum L.) using New Generation Fungicides and Biopesticide
}

\author{
Rini, C.R. ${ }^{* *}$ and Remya, J. ${ }^{2}$ \\ ${ }^{1}$ Agricultural Research Station, Thiruvalla, Kerala Agricultural University, Kerala, India \\ ${ }^{2}$ Pepper Research Station, Panniyur, Kerala Agricultural University, Kerala, India \\ *Corresponding author: crrini@gmail.com (ORCID ID: 0000-0001-7531-896X)
}

Paper No. 818

Received: 20-09-2019

Revised: 23-01-2020

Accepted: 29-02-2020

\begin{abstract}
A field study was conducted to evaluate the efficacy of different new generation fungicides and biopesticide against Phytophthora capsici in black pepper. Five commercial fungicides and a biopesticide were tested and natural infection due to $P$. capsici was recorded. Disease indexing was done by visual observation on leaf blight, spike infection, leaf shedding and yellowing of vines. Among the different fungicides, spraying and drenching with Fenamidone 10WDG + Mancozeb 50WDG @ 0.2\% was found to be the most effective with $12.4 \%$ disease intensity. It was followed by Copper hydroxide 77 WP @ 0.2\% with 17.8\% disease intensity. Dimethomorph 9WP + Mancozeb 60WP and Cymoxanil 8WP + Mancozeb 64WP were also effective against Phytophthora infection and found better than the existing practice of spraying Bordeaux mixture and drenching Copper oxy chloride. Soil application of talc based formulation of PGPM mix @ $50 \mathrm{~g} /$ vine and foliar spray at 2\% concentration also resulted in considerable reduction in the severity of Phytophthora infection in black pepper.

\section{Highlights}

( Application of Fenamidone 10WDG + Mancozeb 50WDG or Copper hydroxide 77 WP@ 0.2\% during $1^{\text {st }}$ week of June, August and October can effectively manage Phtophthora foot rot in black pepper

(- Other effective fungicides include $0.2 \%$ Dimethomorph 9WP + Mancozeb 60WP and Cymoxanil 8WP + Mancozeb 64WP

( Repetitive application of Plant growth promoting microorganisms on to the plant and to the rhizosphere soil will provide better protection against Phytophthora capsici in black pepper.
\end{abstract}

Keywords: Black pepper, Phytophthora foot rot, new generation fungicides, Biopesticides

Black pepper (Piper nigrum L.), the king of spices is a traditional, historic spice crop which has been under cultivation since ancient times in India. Production of black pepper has significantly been affected by foot rot disease caused by Phytophthora capsici (Ravindran 2000). Loss of vines due to this disease is generally $5-20 \%$ (Manohara et al. 2004) which may go even upto $95 \%$ loss in individual gardens (Anandaraj et al. 1989). P. capsici is a polycyclic oomycete plant pathogen against which host resistance is not easily available. Hence an integrated approach involving cultural, biological and chemical control is necessary for successful management of this disease (Anandaraj 2000). Yet chemical control remained as the main focus of management strategy. Prophylactic application of fungicides such as copper based fungicides, metalaxyl and phosphonates are recommended for foot rot management (KAU, 2011 and Anandaraj 2000). However, continuous application of a single molecule of fungicide like Metalaxyl resulted in emergence of resistant isolates of pathogen (Gisi and 
Cohen 1996) and hence combination products like Metalaxyl-Mancozeb are being used (Ramachandran et al. 1991). During heavy monsoon contact fungicides like Copper oxychloride do not give satisfactory control of the disease particularly after the onset of disease (KFRI, 1996). Therefore there is a definite need for more fungicides to incorporate into the integrated disease management plan which can bring down the pathogen population in soil and can control leaf, stem, spike, root and collar infections. Several novel fungicides have been developed in the past two decades with known activity against this oomycete pathogen (Thind 2011). Keeping in view the above mentioned facts, the present study was conducted with the objective of identifying technologies including new generation fungicides and biopesticide for managing Phytophthora infection in black pepper plantations.

\section{MATERIALS AND METHODS}

The trial was conducted for three years during 201314 to 2015-16 at Pepper Research Station, Panniyur. 10 years old black pepper vines of variety Panniyur 1 was chosen for the experiment as this variety is highly susceptible to Phytophthora capsici. The treatments included five commercial fungicides viz., Sectin (Fenamidone 10WDG + Mancozeb 50WDG), Acrobat Mz (Dimethomorph 9WP + Mancozeb 60WP), Curzate M8 (Cymoxanil 8WP + Mancozeb 64WP), Bordeaux Mixture 1\% + Fytran (Copper oxychloride 50WP), Kocide (Copper hydroxide 77 WP), consortium of Plant Growth Promoting Microorganisms (PGPM) and a control. Consortium of PGPM, a fungal-bacterial mix developed by Kerala Agricultural University consisted of four different microorganisms viz., Trichoderma viride, Trichoderma harzianum, Pseudomonas fluorescens and Bacillus megatherium. The experiment was laid out in Randomized block design and each treatment was replicated four times with four plants per replication. The plants were spaced at $4 \times 2 \mathrm{~m}$, and all agronomic practices as per KAU (2011) were adopted. Spraying and drenching with the fungicides were done during $1^{\text {st }}$ week of June (onset of SW monsoon), August (Mid monsoon) and October (onset of NE monsoon) in each year. Natural infection due to Phytophthora attack was recorded at monthly intervals for four months of treatment application i.e. July, August, September and October of all the three years. Disease indexing was done by visual observation on leaf blight, spike infection, leaf shedding and yellowing of vines. Based on the infected area, the experimental plants were rated and had given scores using a score chart of $0-5$ scale. On the $0-5$ scale, $0=$ No infection; $1=1-10 \%$ infection; $2=11-25 \%$ infection; $3=26-50 \%$ infection; $4=51-75 \%$ infection and $5=$ more than $75 \%$ infection. Percent disease intensity was calculated using the following formula and statistically analyzed.

Percent Disease Intensity $(\mathrm{PDI})=$

Sum of all numerical ratings $\times 100$

Total number of leaves observed $x$

Maximum disease score

\section{RESULTS AND DISCUSSION}

Results showed that all the fungicides were significantly superior over control in controlling Phytophthora infection in black pepper (Table 1). In 2013-14, application of Fenamidone + Mancozeb, Dimethomorph + Mancozeb, Cymoxanil + Mancozeb and Copper hydroxide were highly effective and superior over control in reducing Phytophthora infection on leaves. The disease intensity recorded in unprotected control plants was 30.3\% whereas, with the application of these fungicides the intensity of disease was much reduced in the range of 6.7 to $9.3 \%$ i.e., around 69 to $78 \%$ less than control. Besides, these fungicides were found more effective than the existing recommendation wherein the plants were sprayed with Bordeaux mixture 1\% and drenched with Copper oxy chloride @ 0.2\%. Application of PGPM also recorded comparatively less disease $(24.3 \%)$ than the control plants. In 201415, plants treated with Fenamidone + Mancozeb and Copper hydroxide@ $0.2 \%$ recorded the minimum disease of 10.3 and $11 \%$ respectively which was significantly low when compared to control. Application of PGPM was equally effective as that of the above fungicides with $10.7 \%$ disease intensity. It was closely followed by the application of Dimethomorph + Mancozeb and Cymoxanil + Mancozeb. The effects of these fungicides and biopesticide were superior to existing practice of Bordeaux mixture spray + Copper oxy chloride 
Table 1: Percent disease intensity of Phytophthora foot rot infection in black pepper garden

\begin{tabular}{|c|c|c|c|c|c|c|}
\hline \multirow{2}{*}{\multicolumn{2}{|c|}{ Treatments }} & \multicolumn{5}{|c|}{ Percent Disease Intensity* } \\
\hline & & \multirow{2}{*}{$\begin{array}{l}2013-14 \\
9.3(16.9)^{c}\end{array}$} & \multirow{2}{*}{$\begin{array}{l}2014-15 \\
10.3(18.5)^{\mathrm{d}}\end{array}$} & \multirow{2}{*}{$\begin{array}{l}2015-16 \\
17.5(24.4)^{\mathrm{e}}\end{array}$} & \multirow{2}{*}{$\begin{array}{l}\text { Pooled mean } \\
12.4(20.4)^{c}\end{array}$} & \multirow{2}{*}{$\begin{array}{l}\begin{array}{l}\text { \% reduction } \\
\text { over control }\end{array} \\
63.7 \\
\end{array}$} \\
\hline $\mathrm{T} 1$ & $\begin{array}{l}\text { Fenamidone 10WDG + Mancozeb 50WDG } \\
\text { (spray and drench @ } 0.2 \% \text { ) }\end{array}$ & & & & & \\
\hline $\mathrm{T} 2$ & $\begin{array}{l}\text { Dimethomorph 9WP + Mancozeb 60WP } \\
\text { (spray and drench @ } 0.2 \% \text { ) }\end{array}$ & $7.7(15.8)^{\mathrm{c}}$ & $13.3(21.4)^{\mathrm{c}}$ & $37.1(37.5)^{\mathrm{d}}$ & $19.4(25.0)^{\mathrm{bc}}$ & 43.3 \\
\hline T3 & $\begin{array}{l}\text { Cymoxanil 8WP + Mancozeb 64WP (spray } \\
\text { and drench @ 0.2\%) }\end{array}$ & $6.7(14.6)^{\mathrm{c}}$ & $13.0(21.1)^{\mathrm{c}}$ & $45.8(42.6)^{\mathrm{bc}}$ & $21.8(26.2)^{\mathrm{bc}}$ & 36.3 \\
\hline $\mathrm{T} 4$ & $\begin{array}{l}\text { Bordeaux Mixture spray @1\% + Copper } \\
\text { oxychloride drench @ } 0.2 \%\end{array}$ & $19.3(25.7)^{b}$ & $15.7(23.3)^{\mathrm{b}}$ & $49.6(44.8)^{\mathrm{ab}}$ & $28.2(31.4)^{\mathrm{ab}}$ & 17.5 \\
\hline T5 & $\begin{array}{l}\text { Copper hydroxide } 77 \text { WP (spray and } \\
\text { drench @ } 0.2 \% \text { ) }\end{array}$ & $8.3(16.5)^{\mathrm{c}}$ & $11.0(19.3)^{\mathrm{d}}$ & $34.2(35.7)^{\mathrm{d}}$ & $17.8(23.9)^{\mathrm{bc}}$ & 48.0 \\
\hline $\mathrm{T} 6$ & $\begin{array}{l}\text { PGPM spray @ 2\% + soil application @ 50g } \\
\text { vine }^{-1}\end{array}$ & $24.3(29.3)^{\mathrm{ab}}$ & $10.7(19.0)^{\mathrm{d}}$ & $40.0(39.2)^{\mathrm{cd}}$ & $25.0(29.3)^{\mathrm{ab}}$ & 26.9 \\
\hline \multirow[t]{2}{*}{$\mathrm{T} 7$} & Control & $30.3(33.2)^{\mathrm{a}}$ & $18.0(25.1)^{\mathrm{a}}$ & $54.2(47.4)^{\mathrm{a}}$ & $34.2(35.3)^{\mathrm{a}}$ & \\
\hline & $\mathrm{CD}(\mathrm{P}<0.05)$ & 4.5 & 1.6 & 3.7 & 8.1 & \\
\hline
\end{tabular}

Figures in parenthesis are arc sin transformed values.

*Mean of four months

drench similar to the previous year's result. Disease severity during 2015-16, was comparatively higher than the previous years. However a similar trend in disease control was noticed with the fungicides tested recording minimum infection in the treatment with Fenamidone + Mancozeb having percent disease intensity (PDI) $17.5 \%$ followed by Copper hydroxide (PDI 34.2\%) and Dimethomorph + Mancozeb (PDI $37.1 \%$ ). Application of PGPM also recorded very less infection (PDI 40\%) which was better than Bordeaux mixture spray + Copper oxy chloride drench (49.6\% PDI) and the untreated control (54.2\% PDI). Pooled analysis of the three year data revealed that, all the tested fungicides reduced the disease significantly as evidenced by the lower PDI. In all the three years, the best treatment observed was Fenamidone + Mancozeb which reduced the disease by $63.7 \%$ than the control. Next best treatment observed was Copper hydroxide which resulted in $48 \%$ less disease than the control. Dimethomorph + Mancozeb and Cymoxanil + Mancozeb were found better than the existing recommendation of Bordeaux mixture spray and Copper oxy chloride drench and was statistically on par with Copper hydroxide. The effect of Bordeaux mixture and copper oxy chloride in Phytophthora foot rot management is well documented (Ramachandran et al. 1991; Anandaraj and Sarma 1995., KAU, 2011.) and the package has been widely adopted in Kerala. However a number of new fungicide molecules with different mode of action have been evaluated and reported against different species of Phytophthora (Anjaneya et al. 2015; Padmaja et al. 2015). Michael and Martin (2008) reported better survival of pepper plants in soil infested with $P$. capsici when soil was treated with Reason (fenamidone) + Previcur Flex (propamocarb) and Dimethomorph. In the present study, soil application of consortium of PGPM @ 50g/vine + spraying @ 2\% concentration which was repeated twice during the season also resulted in considerable reduction in the severity of Phytophthora infection in black pepper. Similar report on use of biocontrol agents in combination for better disease control was made by Anith and Manomohandas (2001) and Manoranjitham et al. (2001). The fungal - bacterial combination may exert any of their antagonistic mechanisms individually or more than one of them acting simultaneously in synergistic manner for better disease suppression.

\section{CONCLUSION}

The data from this study suggest that fungicides like Fenamidone 10WDG + Mancozeb 50 WDG (Sectin), Copper hydroxide 77 WP (Kocide), Dimethomorph 9WP + Mancozeb 60 WP (Acrobat $\mathrm{Mz}$ ) and Cymoxanil 8WP + Mancozeb 64WP 
(Curzate M8) that are not currently used in black pepper could be included as effective components of a management program against Phytophthora capsici. It is well clear that repetitive application of Plant growth promoting microorganisms on to the plant and to the rhizosphere soil will helps in providing better protection against the dreadful plant pathogen Phytophthora capsici in black pepper.

\section{ACKNOWLEDGEMENTS}

The financial support provided by RKVY and other facilities given by Kerala Agricultural University for conducting the work is gratefully acknowledged here.

\section{REFERENCES}

Anandaraj, M., Abraham, J. and Balakrishnan, R. 1989. Crop loss due to foot rot disease of black pepper. Indian Phytopathol., 42: 473-476.

Anandaraj, M. and Sarma, Y.R. 1995. Diseases of black pepper (Piper nigrum L.) and their management. J. Spices and Aromatic Crops, 4: 17-23.

Anandaraj, M. 2000. Diseases of black pepper. In Black Pepper (Piper nigrum). Ravindran, P. N. (ed.). Harwood Academic Publishers: Amsterdam, The Netherlands, pp. 245-275.

Anith, K.N. and Manomohandas, T.P. 2001. Combined application of Trichoderma harzianum and Alcaligenes sp. strain AMB 8 for controlling nursery rot disease of black pepper. Indian Phytopathol., 54: 335-339.

Anjaneya Reddy, B., Sreenath, A., Rekha, D. and Devappa, V. 2015. Field efficacy of new fungicide molecules against late blight of potato in Southern Karnataka. Abs. In $3^{\text {rd }}$ International Symposium on Phytophthora: Taxonomy, Genomics, Pathogenicity, Resistance and Disease Management, Chowdappa P. Vinayaka Hegde and Muralikrishna, H. (eds.) ICAR-IIHR, Bengaluru, 9-12, September, 2015 pp. 54.

Gisi, U. and Cohen, Y. 1996. Resistance to phenylamide fungicides - A case study with Phytophthora infestans involving mating type and race structure. Annu. Rev. Phytopathol., 34: 549-572.
KAU, 2011. Package of Practices Recommendations: Crops. $14^{\text {th }}$ edition. Directorate of Extension, Kerala Agricultural University, Thrissur, pp. 360.

KFRI, 1996. Fungicidal management of quick wilt disease of black pepper in forest plantations. KFRI Research Report 111, Kerala Forest Research Institute, Peechi, Thrissur, pp. 12.

Manohara, D., Mulya, K. and Wahyuno, D. 2004. Phytophthora disease on black pepper and the control measures. Focus on pepper, 1: 37-49.

Manoranjitham, S.K., Prakasam, V. and Rajappan, K. 2001. Biocontrol of damping off of tomato caused by Pythium aphanidermatum. Indian Phytopathol., 54: 59-61.

Michael E. Matheron and Martin Porchas, 2008. Efficacy of new fungicides as potential management tools for Phytophthora crown and root rot on pepper plants. Vegetable Report, pp. 152.

Padmaja, G., Kanaka Mahalakshmi, B., Uma Devi, G. and Sridevi, D. 2015. Studies on efficacy of fungicides and their dosage against Phytophthora colocasiae causing leaf blight of Taro Abs. In $3^{\text {rd }}$ International Symposium on Phytophthora : Taxonomy, Genomics, Pathogenicity, Resistance and Disease Management, Chowdappa P. Vinayaka Hegde and Muralikrishna, H. (eds.) ICAR-IIHR, Bengaluru, 9-12, September, 2015, pp. 49.

Ramachandran, N., Sarma, Y.R. and Anadaraj, M. 1991. Management of Phytophthora infection in black pepper. In: Sarma Y. R. and Premkumar (Eds) Diseases of Black Pepper. In Proc. International Workshop on Joint Research for the Control of Black Pepper Diseases. 27-28 October 1988, Goa, India, pp. 158-174.

Ravindran, P.N. 2000. Constraints and yield gaps in Black pepper. In Black Pepper (Piper nigrum). Ravindran, P. N. (ed.). Harwood Academic Publishers: Amsterdam, The Netherlands, pp. 497-504.

Thind, T.S. 2011. New generation anti - oomycete fungicides: Prospects and limitations. Pl. Dis. Res., 26: 159. 